\title{
Phase relations of carbonated eclogite under upper mantle PT conditions - implications for carbonatite petrogenesis
}

\author{
Gregory M. Yaxley' and David H. Green'
}

1. Research School of Earth Science. The Australian National University, Canberra, ACT (020), Australia

\section{Introduction}

It has been suggested that carbonated eclogite could act as an upper mantle source for some crustally emplaced carbonatites (Treiman and Essene 1983; Nelson et al. 1988). Relative to mid-ocean ridge basalts, carbonatites have low $\varepsilon_{\mathrm{Nd}}$, high ${ }^{87} \mathrm{Sr} /{ }^{86} \mathrm{Sr}$, and radiogenic $\mathrm{Pb}$-isotopes, and are similar to ocean island basalts (OIBs) (Nelson et al. 1988). These characteristics have been linked to the emplacement of previously subducted oceanic lithosphere into the source regions of OIBs and carbonatites, after long term storage (1-2 Ga) in the mantle (Hofmann and White 1982; Nelson et al. 1988; Hofmann 1997).

Yaxley and Green (1994) demonstrated experimentally that during subduction of carbonate-bearing garnet amphibolite and eclogite (modelling altered oceanic crust), carbonate behaves as a residual, refractory phase forming part of an eclogitic residue in equilibrium with hydrous, highly siliceous partial melts (rhyodacites to dacites). Thus, if carbonate is a constituent of altered oceanic basalt, it is likely to survive subduction into the upper mantle without melting or decarbonation, although it is also sensitive to reduction to graphite or diamond.

However, the high pressure behaviour of residual carbonate in residual anhydrous eclogite from which a highly siliceous melt fraction was extracted during a previous episode of subduction, is currently inadequately constrained by experiment. Carbonate in many basaltic compositions will crystallise at high pressures as calcite-dolomite solid solution [(cc-dol)ss] (Yaxley and Green 1974). Irving and Wyllie (1975) have demonstrated the presence of a minimum melt on the $\mathrm{CaCO}_{3}-\mathrm{CaMg}\left(\mathrm{CO}_{3}\right)_{2}$ join, and the locus of these minimum melts in PT-space lies very close to the soldii of typical oceanic basalt compositions (eg; Green 1982; Yaxley and Green submitted). The presence of $\mathrm{FeO}$ and $\mathrm{Na}_{2} \mathrm{O}$ in natural compositions is expected to lower the temperature of minimum melting of (cc-dol $)_{\mathrm{ss}}$ to below that of the basalt solidus. Coupled with the fact that refractory residual basalt compositions, which crystallise quartz- or coesite-free eclogite at high pressures, are likely to have higher solidus temperatures than typical oceanic basalt compositions, there is the possibility of a high pressure field for carbonatite melt in equilibrium with ga $+\mathrm{cpx}$, at temperatures below the silicate solidus. Accordingly, we have examined the high pressure phase relations of a carbonate-bearing composition (EC1) chosen to crystallise garnet (ga) + clinopyroxene $(\mathrm{cpx})+$ calcite-dolomite solid solution (but not free $\mathrm{SiO}_{2}$ ), under eclogite facies PT conditions.

\section{Experimental techniques}

Composition ECl contained $30.1 \mathrm{wt} \% \mathrm{SiO}_{2}, 11.7 \mathrm{wt} \% \mathrm{Al}_{2} \mathrm{O}_{3}, 19.4 \mathrm{wt} \% \mathrm{CaO}, 12.4 \mathrm{wt} \% \mathrm{MgO}, 10.1$ $\mathrm{wt} \% \mathrm{FeO}, 0.9 \mathrm{wt} \% \mathrm{Na}_{2} \mathrm{O}$ and $15.4 \mathrm{wt} \% \mathrm{CO}_{2}$. A starting mix with this composition was made from sintered oxides and carbonates. $\mathrm{FeO}$ was added as synthetic fayalite. The $\mathrm{ECl}$ mix was encapsulated in 
graphite-lined Pt capsules. Runs were conducted at $3.5 \mathrm{GPa}$ in a standard 1/2" piston cylinder apparatus, using $\mathrm{NaCl}$-pyrex sleeves and a graphite heater.

\section{Experimental Results}

At $\mathrm{P}=3.5 \mathrm{GPa}$ and $\mathrm{T} \leq 1215^{\circ} \mathrm{C}, \mathrm{ECl}$ crystallised sub-solidus assemblages of ga $+\mathrm{cpx}+(\mathrm{cc}-\mathrm{dol})_{\mathrm{ss}}$. At 1250 and $1275^{\circ} \mathrm{C}$ super-solidus assemblages of ga $+\mathrm{cpx}+(\mathrm{cc}-\mathrm{dol})_{\mathrm{ss}}+$ carbonate melt formed. At $1300^{\circ} \mathrm{C}$, carbonate liquid co-existed with ga $+\mathrm{cpx}$ residue.

With increasing temperature, the mole fraction of calcite increased at the expense of the mole fraction of dolomite in unmelted carbonate, and the mole fraction of pyrope increased at the expense of grossular in garnet. For example, carbonate crystallised at $1000^{\circ} \mathrm{C}$ had the composition $\mathrm{CC}_{57} \mathrm{Mag}_{35} \mathrm{Sid}_{8}$ and coexisted with garnet with composition $\mathrm{Gr}_{28} \mathrm{Py}_{42} \mathrm{Alm}_{30}$. Carbonate crystallised at $1275^{\circ} \mathrm{C}$ had the composition $\mathrm{CC}_{86} \mathrm{Mag}_{12} \mathrm{Sid}_{2}$, and co-existed with garnet with composition $\mathrm{Gr}_{22} \mathrm{Py}_{51} \mathrm{Alm} \mathrm{Al}_{27} \mathrm{Ca} / \mathrm{Mg}$ values for cpx's did not vary systematically with temperature.

Carbonate melts exhibited clear quench textures, and a strong tendency to segregate from the ga $+\mathrm{cpx} \pm$ carbonate residues and form a layer at the top of the capsule during the run. These melts were calciodolomitic compositions, and contained 3-4 wt $\% \mathrm{SiO}_{2}, 0.4-1.0 \mathrm{wt} \% \mathrm{Al}_{2} \mathrm{O}_{3}$, and about $65 \mathrm{~mol} \%$ calcite, $25 \mathrm{~mol} \%$ magnesite and $10 \mathrm{~mol} \%$ siderite. $\mathrm{Na}_{2} \mathrm{O}$-contents in the carbonate melts varied from 2.8 to 1.6 wt $\%$ with increasing temperature from $1250-1300^{\circ} \mathrm{C}$. Partition coefficients for $\mathrm{Na}$ between $\mathrm{cpx}$ and melt (cpx/melt) were $\approx 0.2$ at 1250 and $1275^{\circ} \mathrm{C}$. Mg\#'s [atomic $\mathrm{Mg} /\left(\mathrm{Mg}+\sum \mathrm{Fe}\right)$ ] of the carbonate melts varied from 68.3 - 73.3, and were similar to the Mg\# of EC1 (68.8).

\section{Discussion}

A new and significant result of this reconnaisance experimental study is that carbonated eclogite can yield carbonatite melts at temperatures below the eclogite's silicate solidus. This supports suggestions based on trace element abundances and isotopic compositions of carbonatites (eg; Nelson et al. 1988) that ancient, recycled, altered (carbonate-bearing) oceanic crust is a potential source for some crustally emplaced carbonatites

For composition $\mathrm{EC} 1$, carbonatite melt can form at $3.5 \mathrm{GPa}$ at between 1215 and $1250^{\circ} \mathrm{C}$, temperatures well above the carbonate solidus for pyrolite $+\mathrm{CO}_{2}$ (Falloon and Green 1990). If ambient $f \mathrm{O}_{2}$ is sufficiently high to stabilise carbonate, carbonatite melt derived from high pressure partial melting of a discrete body of carbonated eclogite in the peridotitic upper mantle, could rapidly segregate from the eclogitic source at low melt fractions, and percolate into the surrounding peridotite. The melt will re-

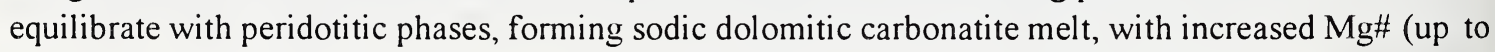
$\approx 85)(n b$; this behaviour contrasts with that exhibited by low degree, highly siliceous melts of eclogite [dacites], which react out of existence with peridotite wall-rock, essentially by replacing olivine with enstatite [Yaxley and Green, submitted]).

The carbonate melt will continue to percolate upwards until it intersects the reaction opx $+\mathrm{dol}=\mathrm{cpx}+$ $\mathrm{ol}+\mathrm{CO}_{2}$ at around $2.0 \mathrm{GPa}$, whereupon decarbonation reactions will result in replacement of peridotitic 
aluminous enstatite with sodic clinopyroxene, driving lherzolitic or harzburgitic lithosphere towards magnesian wehrlite (Green and Wallace 1988). This metasomatic style has been extensively documented in some spinel peridotite xenoliths (eg; Yaxley et al. 1991; Rudnick et al. 1993). Continued influx of metasomatising carbonatite could armour lithospheric wall rock with wehrlitic material, preventing further reaction, and allowing access of carbonatites to shallower depths, and leading ultimately to crustal emplacement (Dalton and Wood 1993; Sweeney et al. 1995).

Eclogite compositions with higher $\mathrm{Na}_{2} \mathrm{O}$ and $\mathrm{FeO}$ contents than $\mathrm{ECl}$ are expected to have carbonate solidii at lower temperatures than EC1. Future experimental studies will be aimed at more completely delineating the PT fields for, and compositions of, carbonatite melts in equilibrium with $\mathrm{EC} 1$ and other eclogitic compositions (varying $\mathrm{Ca} / \mathrm{Mg}$ values, $\mathrm{Na}$ and/or $\mathrm{Fe}$ abundances, for example).

\section{References}

Dalton. J.A. and Wood, B.J., 1993, The compositions of primary carbonate melts and their cvolution through wallrock reaction in the mantle: Earth Planet. Sci. Lett., v. 119, $511-525$.

Falloon, T.J. and Green, D.H., 199(), Solidus of carbonated fertile peridotite underfluid-saturated conditions: Geology, v. 18, 195-199.

Green, T.H., 1982, Anatexis of mafic crust and high pressure crystallization of andesite, in Thorpe. R.S., ed., Andesites: New York, Joln Wilcy \& Sons, p. 465-487.

Green, D. H. and Wallace, M. E., 1988, Mantlc metasomatism by ephemeral carbonatite melts: Nature, v. $336,459-462$.

Hofmann A. W., 1997, Mantle geochemistry: the message from oceanic volcanism: Nature, v. $385,219-229$.

Hofmann. A. W. and White, W. M., 1982, Mantle plumes from ancient oceanic crust: Earth Planet. Sci. Lett., v. 57, 421-436.

Irving. A. and Wyllie, P., 1975. Subsolidus and melting relationships for calcite. magnesite and the join $\mathrm{CaCO}_{3}-\mathrm{MgCO}_{3}$ to $36 \mathrm{~kb}$ : Geochimica et Cosmochimica Acta, v. 39. 35-53.

Nelson, D. R., Clivas, A. R., Cliappell, B. W. and McCulloch, M. T., 1988, Geochemical and isotopic systematics in carbonatites and implications for the evolution of ocean-island sources: Gcochim. Cosmochim. Acta, v. 52, 1-17.
Rudnick, R. L., McDonough, W. F. and Chappcll, B. W., 1993, Carbonatitc metasomatism in the northern Tanzanian mantle: petrographic and geochemical characteristics: Earth Planet. Sci. Lett., v. 114, 463-476.

Swecney, R. J., Falloon, T. J. and Green, D. H., 1995, Experimental constraints on the possible mantle origin of natrocarbonatitc, in Bell, K. and Keller, J., eds., Carbonatite Volcanism: Berlin. Springer-Verlag, p. 189-2(07.

Treiman, A. H. and Essenc, E. J., 1983, Mantle eclogite and carbonate as sources of sodic carbonatites and alkalic magmas: Nature, v. 3()2, 7()()-7()3.

Yaxley, G. M., Crawford, A. J. and Green, D. H., 1991, Evidence for carbonatite metasomatism in spinel peridotite xenoliths from western Victoria, Australia: Earth and Planetary Science Letters, v. 107, 305-317.

Yaxley, G. M. and Green. D. H., 1994. Experimental demonstration of refractory carbonate-bearing eclogite and siliccous melt in the subduction regime: Earth Planet. Sci. Lett., v. 128. 313325.

Yaxlcy, G. M. and Green, D. H., 1998, Reactions between eclogite and peridotitc: Mantle refertilisation by subduction of oceanic crust: submitted to Schweizerische Mineralogische und Petrographische Mittcilungen. 